\title{
Food crop production in Nigeria. II. Potential effects of climate change
}

\author{
James O. Adejuwon* \\ Department of Geography, Obafemi Awolowo University, Ile-Ife, Osun State, Nigeria
}

\begin{abstract}
Two separate lines of investigation were adapted from the recommendations of the 1994 United States Country Studies Program (USCP). In one approach, arbitrary incremental scenarios were adopted to assess the response of crop yield to changes in the various elements of climate. Using the erosion productivity impact calculator (EPIC) crop model, tests were conducted to demonstrate how crop yield might respond to changes in rainfall, relative humidity (RH), temperature, solar radiation and $\mathrm{CO}_{2}$ concentration. The value of one element was altered incrementally while holding constant the values of the others. In the second approach, potential future changes in the yields of maize, sorghum, millet, rice and cassava were simulated based on a scenario specifying mean conditions for 1961-9190 as a baseline and general circulation model (GCM) projections from this for 3 periods: 2010-2039, 2040-2069 and 2070-2099. The results predicted a possible increase in crop yield during the first half of the 21st century to be followed by a decrease during the second half. Enhanced crop yield was explained by projected increases in rainfall, solar radiation, atmospheric humidity and $\mathrm{CO}_{2}$ concentrations. Lower yields were explained in terms of continued global warming, as a result of which maximum and minimum temperatures approach the limits of tolerance for the modelled crops.
\end{abstract}

KEY WORDS: Climate change $\cdot$ Crop yield $\cdot$ Nigeria $\cdot$ Food production Resale or republication not permitted without written consent of the publisher

\section{INTRODUCTION}

\subsection{Objectives and research questions}

In an earlier study (Adejuwon 2005a), the effects of contemporary inter-annual climate variability on the yield of the major food crops in Nigeria were analysed. In the present study, the objective was to characterize changes in crop yield expected as a response to changes in climate during the 21st century. It is now generally accepted that global climate is changing due to increased concentrations of the main greenhouse gases in the atmosphere. Attribution of climate change to human activities, in addition to natural forcing, was addressed by the IPCC Working Group I on Climate Change (Houghton et al. 2001). Globally-averaged surface air temperature is projected to increase by $1.4^{\circ} \mathrm{C}$ to $5.8^{\circ} \mathrm{C}$ by 2100 , relative to 1990 . The projections also indicate that warming could be accompanied by increases or de- creases in precipitation, changes in inter-annual variability of climate, and changes in the frequency and intensity of some extreme weather events such as storms, droughts and floods. The magnitude and spatial and temporal patterns of the changes in each element of climate are expected to vary from one region of the earth's surface to the other.

The present study was designed to determine (1) the specific effects of increased levels of atmospheric $\mathrm{CO}_{2}$ concentrations on crop yield, (2) the specific effects of changes in each of 4 elements of climate (precipitation, relative humidity $[\mathrm{RH}]$, temperature and solar radiation) on crop yield, (3) the effects of aggregate changes in climate on crop yield for maize, sorghum, millet, rice and cassava, (4) possible differences in the effects of climate change on crop yield between one part of Nigeria and the other, and (5) possible changes in the effects of climate change on crop yield in the course of the 21st century. 


\subsection{Study area}

The primary study area was Nigeria, where all vegetation types of the various tropical regional climate categories are present. Thus, northwards from the very humid eastern coastal locations to the boundary with the desert, the vegetation profile includes moist evergreen rain forests, dry semi-evergreen rainforests, Southern Guinea savannah, Northern Guinea savannah, Sudan Savannah, and Sahel Savannah (Fig. 1) (Keay 1959). The rainforest zone, which covers about $25 \%$ of the country, is humid; the Guinea savannah zones, which extend over $40 \%$ of the land area, are sub-humid; while the Sudan savannah and the Sahel zones, constituting about $35 \%$ of the land area, are semi-arid. ('Derived savannah' was originally high forest, before it was converted to savannah as a result of human activities).

Across the various climatic and ecological zones, mean monthly maximum temperature varies between 28 and $40^{\circ} \mathrm{C}$. In coastal locations, mean monthly maximum temperatures are lowest in August at about $28^{\circ} \mathrm{C}$ and highest in March to May (MAM) at around $34^{\circ} \mathrm{C}$. In the sub-humid Guinea zones, mean monthly maximum temperatures are also lowest in August at about $30^{\circ} \mathrm{C}$ and highest in the MAM season averaging $38^{\circ} \mathrm{C}$. In the semi-arid zones, i.e. in the Sudan and Sahel, the highest maximum temperatures are also recorded during the MAM season and can be as high as $40^{\circ} \mathrm{C}$. On the other hand, the lowest maximum temperatures of around $28^{\circ} \mathrm{C}$ are experienced in December or January.
On average, mean monthly minimum temperatures are about $8^{\circ} \mathrm{C}$ lower than mean maximum temperatures in the coastal forest zone. This difference increases to about $15^{\circ} \mathrm{C}$ in the semi-arid zone. While the highest minimum temperatures are observed during the MAM season (i.e. the same months in which the highest maximum temperatures are also observed), the month with the lowest minimum temperatures is January (not August, as is the case with maximum temperatures). The annual range of minimum temperature increases from the humid through the sub-humid to the semi-arid zones. At Port Harcourt, within the rainforest zone, mean monthly minimum temperature varies between 21 and $24^{\circ} \mathrm{C}$; for Ilorin in the subhumid zone, it varies between 17 and $24^{\circ} \mathrm{C}_{i}$ while for Kano in the semi-arid zone, it varies between 12 and $26^{\circ} \mathrm{C}$. Thus nights are relatively cool all over the country during the months MAM. However, in December, January and February, the semi-arid locations experience cold nights compared with the forest zone locations, where night temperatures remain relatively mild.

In the forest zone, the atmosphere is perennially humid with RH always above $70 \%$ at 09:00 h. This is because the area is perennially overlaid by the moist tropical air mass, which has its source in the South Atlantic. In the sub-humid and semi-arid zones, for periods varying in length from 1 to 4 mo, the moist air mass is replaced by a dry tropical air mass, which originates over the Sahara Desert. In the forest zone, mean annual rainfall can be as high as $3000 \mathrm{~mm}$, but usually lies between 1200 and $2000 \mathrm{~mm}$. Although rain

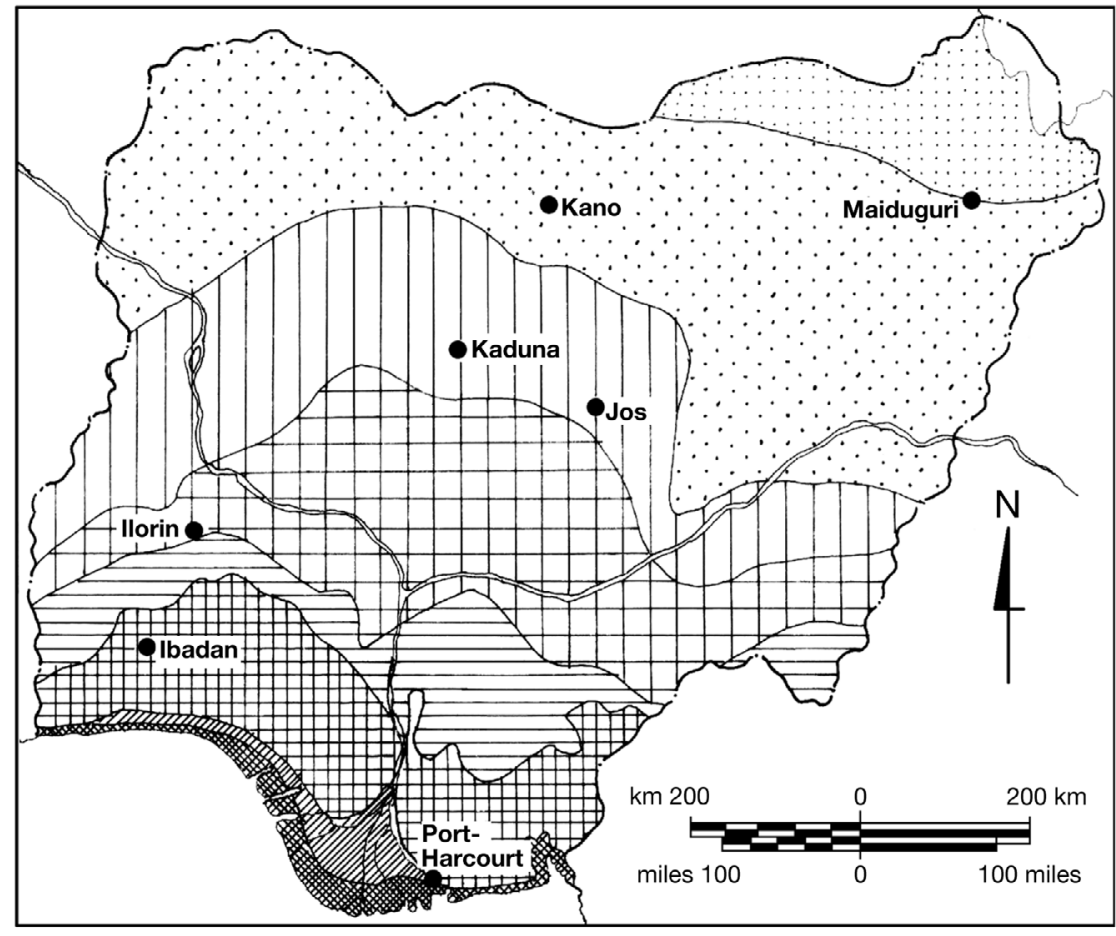

Mangrove forest

Freshwater swamp forest

册 Rainforest

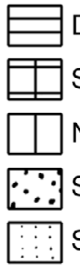

Derived savannah

Southern Guinea savannah

Northern Guinea savannah

$\because \therefore$ Sudan savannah

Sahel savannah

Fig. 1. Nigerian vegetation/ecological zones, and stations employed in this study (bold); see Table 1 for station data 
could be expected during each month, there is usually a relatively dry period of about 2 mo in the southeast and 4 mo in the southwest. In the sub-humid zones, the year is sharply divided into a rainy and dry season. The dry season is about 7 mo long in the northernmost areas, whereas it is only 5 mo long at the boundary with the forest zone. For about 2 of the 5 to 7 months of the dry season, drought is expressed in terms of both low rainfall and low humidity of the air because of the prevalence of the dry air mass invading from the Sahara Desert. There is little difference between the northern drier boundary and the southern wet boundary of the sub-humid zone in terms of total annual rainfall. In fact, the total annual rainfall at Ilorin within the Southern Guinea zone is less than that of Kaduna near the northern boundary of the Northern Guinea zone. However, the boundary between the sub-humid and the semi-arid zones corresponds to a sharp drop in mean annual rainfall from $1000 \mathrm{~mm}$ to about $750 \mathrm{~mm}$. In the Sahel, the rainy season is barely 4 mo long, whereas in the Sudan savannah, the rainy season extends over a period of up to $5 \mathrm{mo}$. In terms of mean annual rainfall, the boundary between the Sahel and Sudan savannah regions is defined by the isohyet of $600 \mathrm{~mm}$.

\section{APPROACHES TO THE ASSESSMENT OF CLIMATE CHANGE AND CROP YIELD}

\subsection{Relating crop yield to climate change}

In a preceding study on the effects of contemporary climate variability on crop yield (Adejuwon 2005a), observed data for both climate and crop yield were used. These were analysed to generate linear models that were interpreted as the effects of climate variability on crop yield. However, for the present study no such data are available, and this represents the fundamental problem in climate change research. When addressing the response of crop yield to future climate, one tool that researchers use is the general circulation model (GCM), which is, in essence, a dynamical or statistical representation of the earth-atmosphere-ocean system. Extended-range GCM-based weather forecasts are issued for West Africa by the MO (Met Office; United Kingdom), the CRC (Centre de Recherches de climatologie; CNRS, France) and the NOAA (National Oceanic and Atmospheric Administration; USA). Another tool is the agro-ecological system model, usually described as the crop model, the building-blocks of which are empirical formulations derived from a large number of in situ experiments on ecosystems. Crop models such as the erosion productivity impact calculator (EPIC) (Williams et al. 1989), the general purpose formulation model of the soil-plant atmosphere system (GAPS) (Butler \& Riha 1989), the decision support systems for agro-technology transfer (DSSAT) (Tsuji et al. 1994) and the soybean crop growth simulation model (SOYGRO) (Jones et al. 1989) are efficient in determining the response of crops to changes in weather and climate. The basic linked systems of national agricultural models (BLS) constructed by the Food and Agricultural Programme at the International Institute for Applied Systems Analysis (IIASA) is also an example of such an approach (Fischer et al. 1988).

Future climates are simulated by introducing higher concentrations of greenhouse gases into a GCM. The outputs of such simulations, in terms of weather and climate elements, are introduced as inputs into the crop model to simulate changes in crop yield. Thus, the crop yield simulated is interpreted as a response to a future climate, which in turn corresponds to a level of greenhouse gas concentration, which in turn corresponds to a predicted future pattern of social and economic activity.

\subsection{Use of incremental scenarios}

In this study 2 separate approaches have been adapted from the recommendations of the United States Country Studies Program (USCP 1994). In the first approach, 'arbitrary (incremental) scenarios (e.g. $+2^{\circ} \mathrm{C}$ and $+4^{\circ} \mathrm{C}$ temperature changes, $\pm 10 \%$ precipitation changes)' were recommended, whereas in the second approach, 'scenarios derived from GCMs' were suggested for estimating potential future changes in yield (see also similar recommendations by Fischer 1996).

In the present study, incremental scenarios were adopted using the EPIC crop model in order to demonstrate the effects of changes in rainfall, $\mathrm{RH}$, temperature, solar radiation and $\mathrm{CO}_{2}$ concentration on crop yield. This approach affords the opportunity to demonstrate the effects of each climate element separately. The value of one element was altered incrementally while holding constant the values of the others.

\subsection{Use of GCM-generated climate change scenarios}

In the second approach, a climate scenario consisting of the mean observed data from 1961-1990 as baseline, and the climate for each of 3 additional periods (2010-2039, 2040-2069, 2070-2099) generated by a GCM, was adopted to simulate potential future changes in crop yield (data available at http://ipcc-ddc.cru. uea.ac.uk). This was an output of the HadCM2 GCM, based on a $1 \%$ per annum compound increase in $\mathrm{CO}_{2}$ 
Table 1. Climate projections for 5 ecological zones in Nigeria 1961-2100, based on data from IPCC (available at http:// ipcc-ddc.cru.uea.ac.uk). Bold: present conditions. Projections are for the year 2100. nc: no change, nsc: no significant change

\begin{tabular}{|c|c|c|c|c|c|}
\hline & Port Harcourt & Ilorin & Kaduna & Kano & Maiduguri \\
\hline \multicolumn{6}{|l|}{ Geography } \\
\hline Region & Forest & Southern Guinea & Northern Guinea & Sudan savannah & Sahel savannah \\
\hline Köppen classification & Af & Aw & Aw & $\mathrm{BS}$ & BS \\
\hline Surface of country (\%) & 25 & 21 & 19 & 28 & 7 \\
\hline \multicolumn{6}{|l|}{ Precipitation } \\
\hline Present amount (mm) & $1200-3000$ & $1000-1250$ & $1000-1250$ & $600-1000$ & $<600$ \\
\hline Rainy season (mo) & $9-12$ & $8-9$ & 6 & 4 & 3 \\
\hline $\begin{array}{r}\text { Projected: Rainy season } \\
\text { Dry season }\end{array}$ & $\begin{array}{l}\text { Wetter } \\
\text { nsc }\end{array}$ & $\begin{array}{l}\text { Wetter } \\
\text { nsc }\end{array}$ & $\begin{array}{l}\text { Wetter and longer } \\
\text { nc }\end{array}$ & $\begin{array}{l}\text { Wetter and earlier } \\
\text { nsc }\end{array}$ & $\begin{array}{l}\text { Wetter until } 2069 \\
\text { nsc }\end{array}$ \\
\hline \multicolumn{6}{|l|}{ Maximum temperature } \\
\hline Present $\left({ }^{\circ} \mathrm{C}\right)$ & $28-34$ & $30-38$ & $30-38$ & $28-40$ & $28-40$ \\
\hline Lowest & August & August & August & January & January \\
\hline Highest & March & March & March & May & May \\
\hline Projected $\left({ }^{\circ} \mathrm{C}\right)$ & $31-36$ & $34-40$ & $34-43$ & $32-43$ & $35-46$ \\
\hline \multicolumn{6}{|l|}{ Minimum temperature } \\
\hline Present $\left({ }^{\circ} \mathrm{C}\right)$ & $21-24$ & $17-24$ & $15-24$ & $12-26$ & $10-26$ \\
\hline Lowest & January & January & January & January & January \\
\hline Highest & April & April & April & May & May \\
\hline Projected $\left({ }^{\circ} \mathrm{C}\right)$ & $21-27$ & $20-30$ & $18-30$ & $19-30$ & $19-30$ \\
\hline \multicolumn{6}{|l|}{ Vapour pressure } \\
\hline Present (hPa) & $27-31$ & $17-28$ & $8-25$ & $5-25$ & $6-25$ \\
\hline Lowest & January & January & January & January & January \\
\hline Highest & April & May & July & August & August \\
\hline Projected (hPa) & $33-38$ & $22-34$ & $12-33$ & $10-32$ & $10-33$ \\
\hline
\end{tabular}

concentration. The data represent choices of GCM experiments and emission scenarios based on the 'worst case' scenario of $\mathrm{CO}_{2}$ increase. It falls into the IPCC climate scenario group that includes IS92e, IS92f, SRES A1F1 and SRES A2, each of which is projected to result in concentrations of greenhouse gases $>850 \mathrm{ppm}$ by the end of the 21st century, from the current level of 370 ppm (Houghton et al. 1995, Nakicenovic \& Swart 2000).

Table 1 summarises climate change projections for Nigeria. The most significant potential changes in climate are with respect to temperature and temperaturerelated parameters. Changes in minimum and maximum temperatures in the order of $5^{\circ} \mathrm{C}$ or more could be expected all over the country. Maximum temperatures may, within this century, attain levels that have no historical precedent outside hot desert regions. This has the potential to increase the wilting coefficient computed in terms of the amount of available moisture. Minimum temperatures are projected to increase at a higher rate than maximum temperatures. A general decrease in cloudiness is projected, which could improve the availability of sunlight for primary production. The adopted scenario indicates that the trend towards aridity in sub-Saharan West Africa during the greater part of the 20th century (Adejuwon et al. 1990, Hulme et al. 2001, Nicholson 2001) could be halted or reversed as the 21st century progresses. Marginal to substantial increases in rainfall are projected for all parts of the country during the rainy season. However, no such increases are projected for the drier parts of the year. Moreover, there are possibilities that the additional water need created by higher temperatures may not be met by projected increases in rainfall. On the other hand, average vapour pressure may rise by as much as 5 to $8 \mathrm{hPa}$ during the growing season, leading to increased $\mathrm{RH}$, which could also result in a reduction in evaporation, lower moisture stress and improved primary production. One aspect of the current climate pattern that will be carried forward into the potential climate of the future is zonation. Rainfall, temperature, cloudiness, incident solar radiation and humidity will decrease or increase, depending on the season, with increasing distance from the ocean in the south.

\subsection{Uncertainties of projected changes}

Accuracy of climate change scenario predictions depends on the skill of the GCM used. Since no two GCMs give exactly the same climate change projections, there is no reliable way of determining which one will be most useful for a specific exercise of climate change projection. Tubiello (2002), for example, demonstrated differential effects of using 2 GCM 
climate change scenarios to simulate crop production in the USA.

Apart from the technical problems presented by the multiplicity of GCMs available, there are difficulties in predicting the true course of future greenhouse gas emissions, which are the required inputs into the climate models. Given the fact that global warming is largely determined by concentrations of the greenhouse gases in the atmosphere, it is hardly surprising that a large proportion of climate change uncertainties is a reflection of uncertainties inherent in the socioeconomic conditions that underlie the greenhouse gas emission projections. In a case study based on Ibadan, southwestern Nigeria, changes in climate based on 1 and $0.5 \%$ increases in equivalent $\mathrm{CO}_{2}$ per annum were compared (Adejuwon \& Omotayo 2006). While the ' $0.5 \%$ ' scenario is projected to make Ibadan warmer by about $3^{\circ} \mathrm{C}$, the ' $1 \%$ ' scenario will create an environment $5^{\circ} \mathrm{C}$ warmer than between 1961 and 1990 . Similarly, a case study looking at climate change in Nigerian climate zones (MOE 2003) reported differing projected increases in precipitation according to the emission scenario used (SRES A2 or B1).

\subsection{EPIC crop model}

The EPIC crop model (version 8120-available at www.brc.tamus.edu/epic) adopted for crop yield simulation in this study was developed by the USA Department of Agriculture (Williams et al. 1989, 1990, Kiniry et al. 1990). EPIC has been employed for the study of the effects of climate on crop growth and development (Cabelguenne et al. 1990, Easterling et al. 1992, 1993, 1996, McKenney et al. 1992, Rollof et al. 1998, Rinaldi 2000). Like other crop models, EPIC represents a simplified crop production system. It consists of non-linear mathematical equations relating crop yield to the underlying physiological processes of growth and development (Ritche 1991). EPIC functions as a series of equations that sequentially estimate potential growth (biomass accumulation) from heat unit accumulation, solar radiation interception, water use and nutrient uptake. Economic yield, the amount of grain, pulse, or tuber that could be removed from the ground in tonnes per hectare, is a derivative of potential growth and a harvest index that is particular to each crop under optimum conditions. Potential crop growth and yield are usually not achieved because of constraints imposed by the plant environment. The model estimates stresses caused by water, nutrients, temperature, aeration, and radiation. In EPIC, the stresses are considered when estimating constraints on biomass accumulation, root growth and yield. Stresses that affect biomass accumulation and root growth will be reflected in the economic yield, which is the output of interest in our simulation exercises.

\subsection{Testing and validating EPIC}

Concern has been expressed over the inadequate validation of model-simulated crop yields, which limits their usefulness in policy analysis (Easterling et al. 1996). The most recent works still fail to address the issues of physiological testing, validation and suitability of the crop models before using them to make projections on crop productivity and production. Using the DSSAT crop model, Tubiello et al. (2002) found significant differences between simulated and observed yields. Percent model error (root mean square error of simulated versus observed yield divided by mean observed yield) was 16 to $25 \%$ across all crops. Coefficient of variation (a measure of risk to farmers) for observed yield was 10 to $15 \%$ compared with 10 to $30 \%$ under simulated irrigated conditions, and 30 to $50 \%$ for simulated rain fed production. In general, simulated yields were observed to be biased towards higher values. These findings notwithstanding, the study advanced to make projections on yield using 2 scenarios of climate change developed with the Hadley Centre model and the Canadian Climate Centre model. With such discrepancies between observed and simulated yields, it could be argued that the projections are of limited credibility. Thus further evidence is required to show that predictions made with such crop model simulations are not too distant from reality.

Validation of the EPIC crop model has been investigated by Kiniry et al. (1990), Easterling et al. (1992, 1996), Rosenberg et al. (1992) and Adejuwon (2005b), among others. Recognising the need for the physiological testing of crop models, Easterling et al. (1996) attempted to improve the validity of EPIC-simulated yield response to climate change. Validity was defined as a reasonably strong covariance of modelled and observed results. The study hypothesized that the performance of crop models during recent years of extreme weather conditions relative to norms of the same period may give a better indication of the validity of crop yield simulations than performance across the full range of climate scenarios, as is commonly studied. The climate record for 1971-1990 in 7 locations in northeastern Nebraska, USA, was separated into normal, extremely warm and extremely cold years. The records were also used to identify years with low, normal and high levels of precipitation. EPIC was used to simulate crop yield with each of the recognized weather classes. Statistical comparisons were made between simulated yields, observed yields 
and observed yields detrended of technology influences. The study concluded that the EPIC model accurately tracks crop yields under observed departures from current temperature norms, thus mimicking the most certain feature of expected climate change-i.e. warming. The study also concluded that the reliability of EPIC simulations during extremely dry years was not as high as during the extremely warm years, but argued that the simulations were still relatively credible.

Adejuwon (2005b) assessed for the first time the suitability of the EPIC crop model to West Africa. Notwithstanding the limitations arising from the need to calibrate for each crop variety, the study confirmed the potential suitability of the crop model not only to site-specific, but also to spatial analytical studies of the impacts of climate variability and climate change on crop yield. With correlation coefficients significant at confidence levels $>95 \%$, the model was used to confirm the known 'real world' sensitivities of maize (0.7759), sorghum (0.7121) and millet (0.7366) to growing season rainfall in the arid zone of the country. Sensitivities to $\mathrm{RH}$, solar radiation and soil were similarly demonstrated. Using the rainfall data for 1986 as input, yields of maize were simulated that varied between 97 and $110 \%$ of average real world yields recorded on experimental farms located in humid, sub-humid and arid zones of the country. In a similar study using 1987 rainfall data, yields of rice were generated that varied between 110 and $117 \%$ of average real world yields on experimental farms within the humid zone. In these experiments, simulated yields were judged to be sufficiently close to reality to be used in the assessment of the impacts of climate variability and climate change.

\subsection{Creation of EPIC data files}

The simulation of crop yield requires the creation of EPIC crop model data files. Therefore, for each farm site adopted for the current study, a principal data file was created with observed data from the period 1961-1990. In the main, the data file includes: program control codes, general site data, water erosion data, climate data, wind erosion data, soil data, management information operation codes and management information operation variables (Williams et al. 1989, 1990, Kiniry et al. 1990). The main data file requires 446 items of input data, 300 of which are the climatic characteristics of each modelled site. As downloaded from the web, the crop model includes such characteristics for all possible selected sites for continental USA. For Nigeria, however, each datum had to be computed using data covering the $30 \mathrm{yr}$ period. For the assess- ment of the impacts of climate change using GCM scenarios, 3 other data files were created with projected data for 2010-2039, 2040-2069 and 2070-2099 respectively. The projected data were substituted for the observed data already in the EPIC data file created with observed 1961-1990 data. To run the model, 2 other files are required. One is an operations schedule file created for each crop, giving details of farm operations and dates of their execution. Another is a soil file with the details of the soil characteristics for the site. The soil used for the simulation has been described at series level in various soil survey reports. It is free draining, loamy in texture and of average productivity. It was adopted as one of the most frequently-used soils for food crop production around the respective modelled localities. For Ibadan the 'Iwo' soil series, derived from igneous and metamorphic rocks (Smyth \& Montgomery 1962), was used to compile the soil file. A savannah zone variant of the same soil series (Murdock et al. 1976) was adopted for the Ilorin site. For the Port Harcourt site the 'Owode' series, derived from coastal sands geological formation (Moss 1957), was used to create the EPIC soil file. The profile used to create the soil file for Jos is a derivative of lava flow identified in a local soil survey (Ibigbami et al. 1979). The same study also included the description of a profile derived from igneous and metamorphic rocks adopted for the creation of the soil file for Kaduna. The soil profiles used for the creation of soil files for Kano and Maiduguri were identified in the report of a survey for a National Agricultural Land Development Agengy (NALDA) farm site at Tikau in Yobe state (Nwaka 1997).

\subsection{Case studies}

The assessment of the effects of climate change on crop productivity reported here was undertaken in 10 case studies. Five of the studies adopted incremental scenarios and were designed to demonstrate the relative effects of individual climate elements on crop yield. Using the EPIC crop model, the elements investigated included rainfall, $\mathrm{RH}$, temperature, solar radiation and $\mathrm{CO}_{2}$. The EPIC data file for Ilorin, in the Southern Guinea savannah ecological zone, was used in the rainfall and RH studies. The file for Ibadan in the rainforest zone was used in the temperature study at low elevation. The data file for Jos (a high altitude site) was used for a repeat of the temperature study. The studies of the relative sensitivities to changes in solar radiation and $\mathrm{CO}_{2}$ were also conducted with the Jos data file. The other 5 case studies adopted GCM scenarios. Each of the studies in this group was designed to demonstrate changes in simulated yield of a particular crop, from the baseline of 1961-1990 through 3 other periods in- 
cluding 2010-2039, 2040-2069 and 2070-2099. Only 5 crops (maize, millet, sorghum, rice and cassava) were investigated. The other major crop, yam, was not in the crop list of EPIC. It was for these series of studies that outputs of the HadCM2 data were adopted.

\section{METHODS}

\subsection{Response of crops to individual climate parameters}

Maize, sorghum, millet and rice were investigated for sensitivity to climate factors, using incremental scenarios. The Ilorin study on the effects of changing seasonal rainfall on crop yield adopted the EPIC data file (created with 1961-1990 observed data) as the baseline of a 4-member scenario. The three other members of the scenario were created by increasing the monthly rainfall values by 5,10 and $15 \%$. EPIC simulations were conducted with these data files and the outputs demonstrate the changes that could occur in crop yield if the climate were to become generally wetter. The same strategy was adopted to assess the possible effects of changing RH on crop yield, also using an initial data file created for Ilorin. Fakorede (1985) tested the effects of increasing rainfall and increasing $\mathrm{RH}$ on the yields of crops planted early (March) and later (May), observing that planting early in the rainy season tends to result in higher yields.

To assess the effects of changing temperature on crop yield, the main EPIC data files created for Ibadan (lowland) and Jos (upland) with the observed data for the period 1961-1990 (baseline) were employed. The 2-site experiment design for the assessment of the effects of temperature incorporates the difference in baseline temperatures between high and low altitude locations. Mean monthly temperature for Jos is, on average, lower than mean monthly temperature for Ibadan by about $8^{\circ} \mathrm{C}$. The characteristics for Ibadan are similar to those of Port Hacourt within the forest zone. However, the characteristics for Jos are unique in Nigeria being comparable only to those observable on the East African Plateau in Kenya. Changing the values for monthly minimum and maximum temperatures in the baseline data files created 4 other data files. To create the 2 nd, $3 \mathrm{rd}, 4$ th and 5 th files, 1, 2, 2 and $4{ }^{\circ} \mathrm{C}$, respectively, were added to the values of the monthly maximum temperature, and at the same time, $2,2,3$ and $5^{\circ} \mathrm{C}$, respectively, were added to the values of the monthly minimum temperature.

For the assessment of the effects of changing solar radiation and $\mathrm{CO}_{2}$ concentrations, the EPIC file created for Jos using 1961-1990 observed data represented the baseline climate. The incremental scenario for solar radiation included 3 other files, with values of solar radiation increased by 5,10 and $15 \%$ in succession. For the $\mathrm{CO}_{2}$ concentration levels, the scenario consisted of data files with concentrations of 350,370 , 500 and $650 \mathrm{ppm}$.

\subsection{Effects of changing climate on crop yield}

The climate change scenario outlined in Section 2.3 was used in creating EPIC data files for 6 sites and 4 periods (1961-1990 [baseline], 2010-2039, 2040-2069 and 2070-2099). The sites represented 5 ecological zones: the moist rainforest, Southern Guinea savannah, Northern Guinea savannah, Sudan savannah and Sahel savannah as well as the high altitude Jos Plateau. The 5 crops involved in the assessment included: maize, sorghum, millet, rice and cassava.

\subsection{Interpretation of EPIC-run outputs}

The output of the model runs included not only the yield of the crops, but also the numbers of days of water stress, nitrogen stress, phosphorus stress, temperature stress and aeration stress (when too much water in the soil fills all the spaces between soil particles). Stress occurs on such days when the crop's specific needs are fulfilled to a level below the crop's tolerance. Crop yields simulated for each period were used to characterize changes in crop yield from 1961-1990 to 2070-2099. When interpreting the patterns of changes in crop yield, the climate-related stresses were first considered. In addition, changes in the elements of climate as arbitrarily introduced or as outlined earlier in the climate change scenario were also considered.

\section{EFFECTS OF INCREASES IN CLIMATE PARAMETERS ON CROP YIELD}

\subsection{Precipitation}

Table 2 depicts crop yield responses to changing rainfall and $\mathrm{RH}$ components of climate while values of the other elements were held constant at baseline levels. Baseline yields for March plantings were higher than those for May plantings for all the crops. This confirms the findings of Fakorede (1985) that grain yield of maize decreases by 30,38 , and $34 \mathrm{~kg} \mathrm{ha}^{-1}$ for each day that planting is delayed after the first planting in March 1978, 1980 and 1981 respectively. The effects on yields of increases in rainfall of up to $15 \%$ are marginal, regardless of whether crops were planted in March (at the beginning of the season) or May (when 
Table 2. Crop yield sensitivity to changing precipitation and changing relative humidity at Ilorin. Baseline = mean climate 1961-1990; $\mathrm{II}=$ baseline $+5 \%$; III = baseline $+10 \%$; IV = baseline $+15 \%$; Y yield $\left(\mathrm{t} \mathrm{ha}^{-1}\right) ; \% \mathrm{ch}=\%$ change in yield from baseline; ws $=$ water stress $(\mathrm{d})$; ts $=$ temperature stress $(\mathrm{d}) ;$ as $=$ aeration stress $(\mathrm{d})$

\begin{tabular}{|c|c|c|c|c|c|c|c|c|c|c|c|c|c|c|c|c|c|c|c|c|}
\hline \multirow{2}{*}{ Climate } & \multicolumn{5}{|c|}{ Maize $^{-}$} & \multicolumn{5}{|c|}{ Sorghum } & \multicolumn{5}{|c|}{ Millet -} & \multicolumn{5}{|c|}{ - Rice- } \\
\hline & $\mathrm{Y}$ & $\% \mathrm{ch}$ & ws & ts & as & $\mathrm{Y}$ & $\% \mathrm{ch}$ & ws & ts & as & $\mathrm{Y}$ & $\% \mathrm{ch}$ & ws & ts & as & $\mathrm{Y}$ & $\% \mathrm{ch}$ & ws & ts & as \\
\hline \multicolumn{21}{|c|}{ CHANGING PRECIPITATION } \\
\hline \multicolumn{21}{|c|}{ March plantings } \\
\hline Baseline & 4.696 & & 15.3 & 3.1 & 0.0 & 3.825 & & 14.4 & 0.5 & 0.0 & 1.559 & & 6.9 & 0.1 & 0.0 & 1.811 & & 0.5 & 7.5 & 0.0 \\
\hline II & 4.705 & 0.2 & 15.2 & 3.1 & 0.0 & 3.831 & 0.2 & 14.3 & 0.5 & 0.0 & 1.562 & 0.2 & 6.8 & 0.1 & 0.0 & 1.811 & 0.0 & 0.5 & 7.5 & 0.0 \\
\hline III & 4.713 & 0.4 & 15.1 & 3.1 & 0.0 & 3.838 & 0.3 & 14.2 & 0.5 & 0.0 & 1.564 & 0.3 & 6.7 & 0.1 & 0.0 & 1.811 & 0.0 & 0.5 & 7.5 & 0.0 \\
\hline IV & 4.727 & 0.7 & 15.0 & 3.1 & 0.0 & 3.849 & 0.6 & 14.1 & 0.5 & 0.0 & 1.568 & 0.6 & 6.6 & 0.1 & 0.0 & 1.812 & 0.01 & 0.5 & 7.5 & 0.0 \\
\hline \multicolumn{21}{|c|}{ May plantings } \\
\hline Baseline & 4.065 & & 2.2 & 1.2 & 16.3 & 2.888 & & 2.1 & 0.2 & 18.4 & 0.852 & & 1.3 & 0.6 & 21.2 & 1.175 & & 0.4 & 2.5 & 0.0 \\
\hline II & 4.058 & -0.2 & 2.2 & 1.2 & 16.6 & 2.876 & -0.4 & 2.1 & 0.2 & 18.7 & 0.849 & -0.4 & 1.3 & 0.6 & 21.5 & 1.175 & 0.0 & 0.4 & 2.5 & 0.0 \\
\hline III & 4.026 & -0.6 & 2.2 & 1.2 & 17 & 2.859 & -1.0 & 2.0 & 0.2 & 19.1 & 0.846 & -0.8 & 1.3 & 0.5 & 22.0 & 1.175 & 0.0 & 0.4 & 2.5 & 0.0 \\
\hline IV & 3.953 & -2.8 & 2.2 & 1.0 & 18.4 & 2.816 & -2.5 & 2.0 & 0.1 & 20.4 & 0.840 & -1.4 & 1.3 & 0.4 & 23.1 & 1.175 & 0.0 & 0.4 & 2.5 & 0.0 \\
\hline \multicolumn{21}{|c|}{ CHANGING RELATIVE HUMIDITY } \\
\hline \multicolumn{21}{|c|}{ March plantings } \\
\hline Baseline & 4.696 & & 15.3 & 3.1 & 0.0 & 3.825 & & 14.4 & 0.5 & 0.0 & 1.559 & & 6.9 & 0.4 & 0.0 & 1.811 & & 0.5 & 7.5 & 0.0 \\
\hline II & 4.911 & 4.6 & 15.3 & 3.1 & 0.0 & 4.002 & 4.6 & 14.4 & 0.5 & 0.0 & 1.646 & 5.6 & 6.8 & 0.1 & 0.0 & 1.898 & 4.8 & 0.5 & 0.5 & 0.0 \\
\hline III & 5.079 & 8.2 & 15.2 & 3.1 & 0.0 & 4.140 & 8.2 & 14.3 & 0.5 & 0.0 & 1.712 & 9.8 & 6.8 & 0.1 & 0.0 & 1.946 & 7.5 & 0.5 & 0.5 & 0.0 \\
\hline IV & 5.262 & 12.1 & 15.2 & 3.1 & 0.0 & 4.289 & 12.1 & 14.3 & 0.5 & 0.0 & 1.785 & 14.5 & 6.8 & 0.1 & 0.0 & 2.042 & 12.8 & 0.5 & 0.5 & 0.0 \\
\hline \multicolumn{21}{|c|}{ May plantings } \\
\hline Baseline & 4.065 & & 2.2 & 1.2 & 16.3 & 2.888 & & 2.1 & 0.2 & 18.4 & 0.852 & & 1.3 & 0.6 & 21.2 & 1.175 & & 0.4 & 2.5 & 0.0 \\
\hline II & 4.289 & 5.5 & 2.2 & 1.2 & 16.4 & 3.048 & 5.5 & 2.1 & 0.2 & 18.5 & 0.907 & 6.4 & 1.3 & 0.6 & 21.3 & 1.230 & 4.6 & 0.4 & 2.5 & 0.0 \\
\hline III & 4.500 & 11 & 2.2 & 1.2 & 16.5 & 3.199 & 11 & 2.1 & 0.2 & 18.6 & 0.960 & 13 & 1.3 & 0.6 & 21.4 & 1.284 & 9.2 & 0.4 & 2.5 & 0.0 \\
\hline IV & 4.670 & 15 & 2.2 & 1.2 & 16.6 & 3.319 & 15 & 2.1 & 0.2 & 18.7 & 0.999 & 17 & 1.3 & 0.6 & 21.5 & 1.324 & 13 & 0.4 & 2.5 & 0.0 \\
\hline
\end{tabular}

the rainy season was well under way) (Table 2). Increasing rainfall did not result in either a decrease in water stress or an increase in aeration stress for crops planted in March, as one would expect, and marginal changes in yield were positive. For crops planted in May there were also no significant changes in water stress in response to increases in rainfall up to $15 \%$. However, there were increases of up to $2 \mathrm{~d}$ in aeration stress for maize, sorghum and millet, while the level of aeration stress remained constant for rice. Perhaps the most significant observation from Table 2 is that increasing rainfall for crops planted in May appeared to produce lower yields. An increase of $15 \%$ in rainfall produced a decrease of $2.8 \%$ in the yield of maize, a decrease of $2.2 \%$ in the yield of sorghum and a decrease of $1.4 \%$ in the yield of millet. The yield of rice was not affected.

\subsection{Relative humidity}

As depicted in Table 2 the increases in yield associated with increased RH were much higher than those associated with increases in precipitation. An increase in $\mathrm{RH}$ by $15 \%$ led to yield increases of 12 to $17 \%$ under the different scenarios. Changes in $\mathrm{RH}$ and yield were not associated with changes in either water stress, temperature stress or aeration stress.

\subsection{Temperature}

The effects of increasing temperature on crop yield are depicted in Table 3, which shows EPIC-simulated yields for the baseline situation, as well as for 4 scenarios of increased temperature, at the low and high elevation sites. For the 4 crops investigated, the baseline-simulated yields for the low elevation site were higher than those for the high altitude location by factors varying from $75 \%$ for maize, $133 \%$ for sorghum, $300 \%$ for millet to $1200 \%$ for rice. The results for the low elevation site indicate increases in the simulated yields corresponding to increases in temperature for all crops. However, the rate of increase declined and the decline became more pronounced with increasing temperature. The point in the climate scenario at which the rates of crop yield increase started to decline varied. For maize, sorghum, millet, and rice (respectively), this was at the point when the increase in maximum/minimum temperature was $2 / 3^{\circ} \mathrm{C}$ (Climate IV), $4 / 5^{\circ} \mathrm{C}$ (Climate V), $4 / 5^{\circ} \mathrm{C}$ (Climate V) and $2 / 2^{\circ} \mathrm{C}$ (Climate III). For maize and rice, yields resulting from the simulations with the highest temperatures (Climate V) were lower than yields simulated with the baseline temperatures (11 and 22\% lower, respectively).

The reductions in yield at the higher levels of temperature were due to increased temperature stress. At Ibadan, the baseline (Climate I) conditions produced no temperature stress for millet and sorghum, $1 \mathrm{~d}$ of 
Table 3. Crop yield sensitivity to changing temperature at Ibadan and Jos. Baseline $=$ mean climate 1961-1990; II = baseline maximum temperature $+1^{\circ} \mathrm{C}$, minimum temperature $+2^{\circ} \mathrm{C}_{i}$ III $=$ baseline maximum temperature $+2^{\circ} \mathrm{C}$, minimum temperature $+2^{\circ} \mathrm{C} ;$ IV $=$ baseline maximum temperature $+2^{\circ} \mathrm{C}$, minimum temperature $+3^{\circ} \mathrm{C} ; \mathrm{V}=$ baseline maximum temperature $+4^{\circ} \mathrm{C}$, minimum temperature $+5^{\circ} \mathrm{C} ;$ Y: yield $\left(\mathrm{t}\right.$ ha ${ }^{-1}$ ); $\% \mathrm{ch}=\%$ change in yield from baseline; ws = water stress $(\mathrm{d})$; ts = temperature stress $(\mathrm{d})$; as = aeration stress (d)

\begin{tabular}{|c|c|c|c|c|c|c|c|c|c|c|c|c|c|c|c|c|c|c|c|c|}
\hline \multirow[t]{2}{*}{ Climate } & \multirow[b]{2}{*}{$\mathrm{Y}$} & \multirow{2}{*}{$\% \mathrm{ch}$} & \multicolumn{3}{|c|}{ Maize } & \multicolumn{5}{|c|}{ Sorghum } & \multicolumn{5}{|c|}{ _ Millet } & \multicolumn{5}{|c|}{ - Rice - } \\
\hline & & & ws & ts & as & $\mathrm{Y}$ & $\%$ ch & ws & ts & as & $\mathrm{Y}$ & $\% \mathrm{ch}$ & ws & ts & as & $\mathrm{Y}$ & $\%$ ch & ws & ts & as \\
\hline \multicolumn{21}{|c|}{ Low altitude (Ibadan), $225 \mathrm{~m}$ a.s.l. } \\
\hline Baseline & 4.585 & & 8.5 & 1.0 & 11.9 & 3.523 & & 7.8 & 0.0 & 12.4 & 1.256 & & 2.4 & 0.1 & 17.6 & 2.987 & & 0.5 & 4.1 & 0.0 \\
\hline II & 4.873 & 6.3 & 7.2 & 3.1 & 12.1 & 3.990 & 13.3 & 7.8 & 0.2 & 12.7 & 1.439 & 14.6 & 2.5 & 0.0 & 17.6 & 3.312 & 10.9 & 0.7 & 8.9 & 0.0 \\
\hline III & 4.918 & 7.3 & 8.2 & 4.6 & 9.8 & 4.046 & 14.8 & 9.3 & 0.4 & 11.0 & 1.492 & 18.8 & 3.9 & 0.0 & 14.7 & 3.261 & 9.2 & 1.6 & 11.1 & 0.0 \\
\hline IV & 4.895 & 6.8 & 6.9 & 5.7 & 11.3 & 4.102 & 16.4 & 8.2 & 0.7 & 12.2 & 1.503 & 19.7 & 3.2 & 0.0 & 16.2 & 3.131 & 4.8 & 1.5 & 13.1 & 0.0 \\
\hline $\mathrm{V}$ & 4.101 & -11 & 6.8 & 12.1 & 0.0 & 3.625 & 2.9 & 7.9 & 3.7 & 9.7 & 1.360 & 8.3 & 4.1 & 0.3 & 13.0 & 2.323 & -22 & 2.4 & 22.8 & 0.0 \\
\hline \multicolumn{21}{|c|}{ High altitude (Jos), $1295 \mathrm{~m}$ a.s.l. } \\
\hline Baseline & 2.592 & & 5.1 & 8.0 & 0.0 & 1.534 & & 1.2 & 18.4 & 0.0 & 0.310 & & 1.4 & 24.8 & 0.0 & 0.221 & & 11.1 & 9.7 & 0.0 \\
\hline II & 2.693 & 4.2 & 8.6 & 3.7 & 0.0 & 1.917 & 24.0 & 1.4 & 11.3 & 0.0 & 0.438 & 41.3 & 0.0 & 18.4 & 0.0 & 0.435 & 106 & 7.9 & 4.8 & 0.0 \\
\hline III & 2.695 & 4.3 & 10.3 & 2.9 & 0.0 & 1.991 & 29.8 & 2.4 & 9.2 & 0.0 & 0.471 & 51.9 & 0.0 & $16 . .5$ & 0.0 & 0.532 & 141 & 7.2 & 3.8 & 0.0 \\
\hline IV & 2.709 & 4.9 & 11.7 & 2.0 & 0.0 & 2.060 & 34 & 3.7 & 7.3 & 0.0 & 0.510 & 64.5 & 0.0 & 14.3 & 0.0 & 0.625 & 183 & 7.3 & 2.6 & 0.0 \\
\hline $\mathrm{V}$ & 3.304 & 28.0 & 16.4 & 0.4 & 0.0 & 2.384 & 55.4 & 9.2 & 2.6 & 0.0 & 0.887 & 184 & 0.1 & 7.6 & 0.0 & 0.814 & 268 & 10.7 & 0.5 & 0.0 \\
\hline
\end{tabular}

temperature stress for maize and $4 \mathrm{~d}$ of stress for rice. However, conditions represented by Climate $\mathrm{V}$ produced $23 \mathrm{~d}$ of temperature stress for rice and $12 \mathrm{~d}$ of stress for maize. Temperature stresses for sorghum and millet were still relatively low at 4 and $0.3 \mathrm{~d}$, respectively. At the high altitude site, temperature stress was highest for the baseline climate, which probably resulted from low temperature. With higher temperatures, temperature stress declined and the yield improved. For the baseline climate, temperature stress was $8 \mathrm{~d}$ for maize, $18 \mathrm{~d}$ for sorghum, $25 \mathrm{~d}$ for millet and $10 \mathrm{~d}$ for rice. However, the conditions represented by Climate $\mathrm{V}$ produced no temperature stress for maize, only $3 \mathrm{~d}$ of stress for sorghum, $8 \mathrm{~d}$ for millet and $<1 \mathrm{~d}$ for rice. This seems to explain why there was less curtailment of yield at the higher levels of temperature.

Baseline water stress of $6 \mathrm{~d}$ for maize, $8 \mathrm{~d}$ for sorghum and $2 \mathrm{~d}$ for millet did not change markedly with increasing temperature. Furthermore, no water stress was associated with changes in yield and corresponding changes in temperature. None of the climates used for yield simulation produced aeration stress for rice. Baseline aeration stress of 12, 12 and $17 \mathrm{~d}$ was experienced by maize, sorghum and millet, respectively. With the exception of maize and for Climate $\mathrm{V}$, there were only marginal reductions in aeration stress corresponding to increases in temperature. Yield simulation with Climate V produced no aeration stress.

Table 3 shows that across the range of temperature situations, there were corresponding increases in yield at the higher altitude. Thus, percentage changes in yield also increased with changes in temperature. In this respect the pattern contrasted strongly with that obtained at the lower elevation at Ibadan, where there were reductions in percentage changes at some points as the climate became warmer.
At the high altitude site, there was no aeration stress recorded for any of the crops under any of the climates adopted for the simulation of yield. For maize and sorghum, water stress increased as temperature increased from baseline climate to Climate V. For rice there was a decline in water stress from baseline climate to Climate IV, but an increase under Climate V conditions. For millet, water stress remained at minimal levels from baseline to Climate V. Temperature stress declined for all crops from baseline to Climate V. These results indicate that the positive effects of declining temperature stress were able to override the negative effects of increasing water stress (e.g. for maize, a decrease in temperature stress from 8 to $0 \mathrm{~d}$ was sufficient to override an increase in water stress from $5 \mathrm{~d}$ to $16 \mathrm{~d}$ and produce a substantial increase of $28 \%$ over baseline yield).

\subsection{Solar radiation}

The first part of Table 4 depicts the pattern of response of the 4 crops to different levels of solar radiation. For each crop, the increases in yield were continuous, regular and considerable, and more or less at the same percentage levels as increases in solar radiation. Thus, percentage changes in yield also increased with changes in the amounts of solar radiation received. The increases observed with respect to maize were less than those for the other crops. However, even with conditions represented by Climate IV, which included increases of $15 \%$ solar radiation, the yields of millet and rice remained at uneconomical levels. There was no aeration stress recorded for any of the crops under any of the climates adopted for the simulation of yield. For maize, water stress doubled from baseline to 
Table 4. Crop yield sensitivity to changing solar radiation and changing $\mathrm{CO}_{2}$ concentrations at Jos. Baseline $=$ mean climate $1961-1990\left(\mathrm{CO}{ }_{2}\right.$ concentration $350 \mathrm{ppm})_{i} \mathrm{II}=$ baseline solar radiation $+5 \%\left(\mathrm{CO}_{2} \text { concentration } 370 \mathrm{ppm}\right)_{i}$ III = baseline solar radiation $+10 \%\left(\mathrm{CO}_{2}\right.$ concentration $500 \mathrm{ppm}) ; \mathrm{IV}=$ base-line solar radiation $+15 \%\left(\mathrm{CO}_{2}\right.$ concentration $\left.650 \mathrm{ppm}\right) ; \mathrm{Y}=$ yield $\left(\mathrm{t} \mathrm{ha}^{-1}\right) ; \% \mathrm{ch}=\%$ change in yield from baseline; ws $=$ water stress $(d)$; ts $=$ temperature stress $(d)$; as = aeration stress $(d)$;

\begin{tabular}{|c|c|c|c|c|c|c|c|c|c|c|c|c|c|c|c|c|c|c|c|c|}
\hline \multirow[t]{2}{*}{ Climate } & \multicolumn{5}{|c|}{ Maize } & \multicolumn{5}{|c|}{ _ Sorghum- } & \multicolumn{5}{|c|}{ _ Millet } & \multicolumn{5}{|c|}{ _Rice } \\
\hline & $\mathrm{Y}$ & $\% \mathrm{ch}$ & ws & ts & as & $\mathrm{Y}$ & $\% \mathrm{ch}$ & ws & ts & as & $\mathrm{Y}$ & $\%$ ch & ws & ts & as & $\mathrm{Y}$ & $\% \mathrm{ch}$ & ws & ts & as \\
\hline \multicolumn{21}{|c|}{ Solar radiation } \\
\hline Baseline & 2.582 & & $5.1^{\prime}$ & 8.0 & 0.0 & 1.534 & & 1.2 & 18.4 & 0.0 & 0.310 & & 1.4 & 24.8 & 0.0 & 0.221 & & 11.1 & 9.7 & 0.0 \\
\hline II & 2.615 & 1.3 & 6.9 & 7.8 & 0.0 & 1.615 & 5.3 & 0.2 & 18.6 & 0.0 & 0.326 & 5.2 & 0.5 & 25.0 & 0.0 & 0.233 & 5.4 & 10.2 & 9.1 & 0.0 \\
\hline III & 2.628 & 1.8 & 8.5 & 7.8 & 0.0 & 1.688 & 10.0 & 0.6 & 18.2 & 0.0 & 0.342 & 10.3 & 0.5 & 25.0 & 0.0 & 0.244 & 10.4 & 10.5 & 9.7 & 0.0 \\
\hline IV & 2.639 & 2.2 & 10.1 & 7.5 & 0.0 & 1.754 & 14.3 & 1.2 & 17.9 & 0.0 & 0.357 & 15.2 & 0.5 & 25.0 & 0.0 & 0.253 & 14.5 & 11.8 & 9.7 & 0.0 \\
\hline \multicolumn{21}{|c|}{$\mathrm{CO}_{2}$ concentration } \\
\hline Baseline & 2.582 & & 5.1 & 8.0 & 0.0 & 1.534 & & 1.2 & 18.4 & 0.0 & 0.310 & & 1.4 & 24.8 & 0.0 & 0.221 & & 11.1 & 9.7 & 0.0 \\
\hline II & 2.618 & 1.4 & 5.1 & 8.0 & 0.0 & 1.555 & 1.4 & 1.2 & 18.4 & 0.0 & 0.315 & 1.6 & 1.4 & 24.8 & 0.0 & 0.226 & 2.2 & 11.1 & 9.7 & 0.0 \\
\hline III & 2.758 & 5.3 & 5.1 & 8.0 & 0.0 & 1.635 & 6.6 & 1.2 & 18.4 & 0.0 & 0.338 & 9.0 & 1.4 & 24.8 & 0.0 & 0.252 & 14.0 & 11.1 & 9.7 & 0.0 \\
\hline IV & 2.792 & 8.1 & 5.1 & 8.0 & 0.0 & 1.642 & 7.0 & 1.2 & 18.4 & 0.0 & 0.348 & 12.3 & 1.4 & 24.8 & 0.0 & 0.267 & 20.8 & 11.1 & 9.7 & 0.0 \\
\hline
\end{tabular}

Climate IV. Baseline water stress for sorghum, millet and rice did not change significantly, whereas the other elements of the scenario were adopted for simulating crop yield. Temperature stress also remained at baseline levels for simulations that adopted Climates II, III and IV. The minimum response in the form of changes in stress factors is understandable. Because solar radiation is the basis for primary biological production, its effect on crop yield is directly and positively proportional to crop yield.

\section{EFFECTS OF CLIMATE CHANGE ON CROP YIELD}

\subsection{Maize}

The general pattern in changes in the yield of maize (Fig. 2) is an initial increase from Period 1 (1961-1990) to Period 2 (2010-2039), followed by a decline from Period 3 (2040-2069) to Period 4 (2070-2099). The exception is at Jos, which represents high altitude ecology. The lowest yield for Jos

\subsection{Carbon dioxide}

Table 4 (second part) depicts changes in simulated crop yield that correspond to increases in $\mathrm{CO}_{2}$ concentration from 350 to $650 \mathrm{ppm}$. Increases were observed across the range of concentrations; however, for all crops (especially for maize and sorghum), the rate of increase in yield per unit increase in concentration tended to decline at the higher levels of $\mathrm{CO}_{2}$ concentration. For example, for sorghum, the $130 \mathrm{ppm}$ change in concentration between Climate II and Climate III was responsible for a $5.2 \%$ change in yield, while the greater $150 \mathrm{ppm}$ change in concentration between Climate III and Climate IV was associated with a change of only $0.4 \%$. Water stress, temperature stress and aeration stress remained at baseline levels across the range of $\mathrm{CO}_{2}$ concentrations.
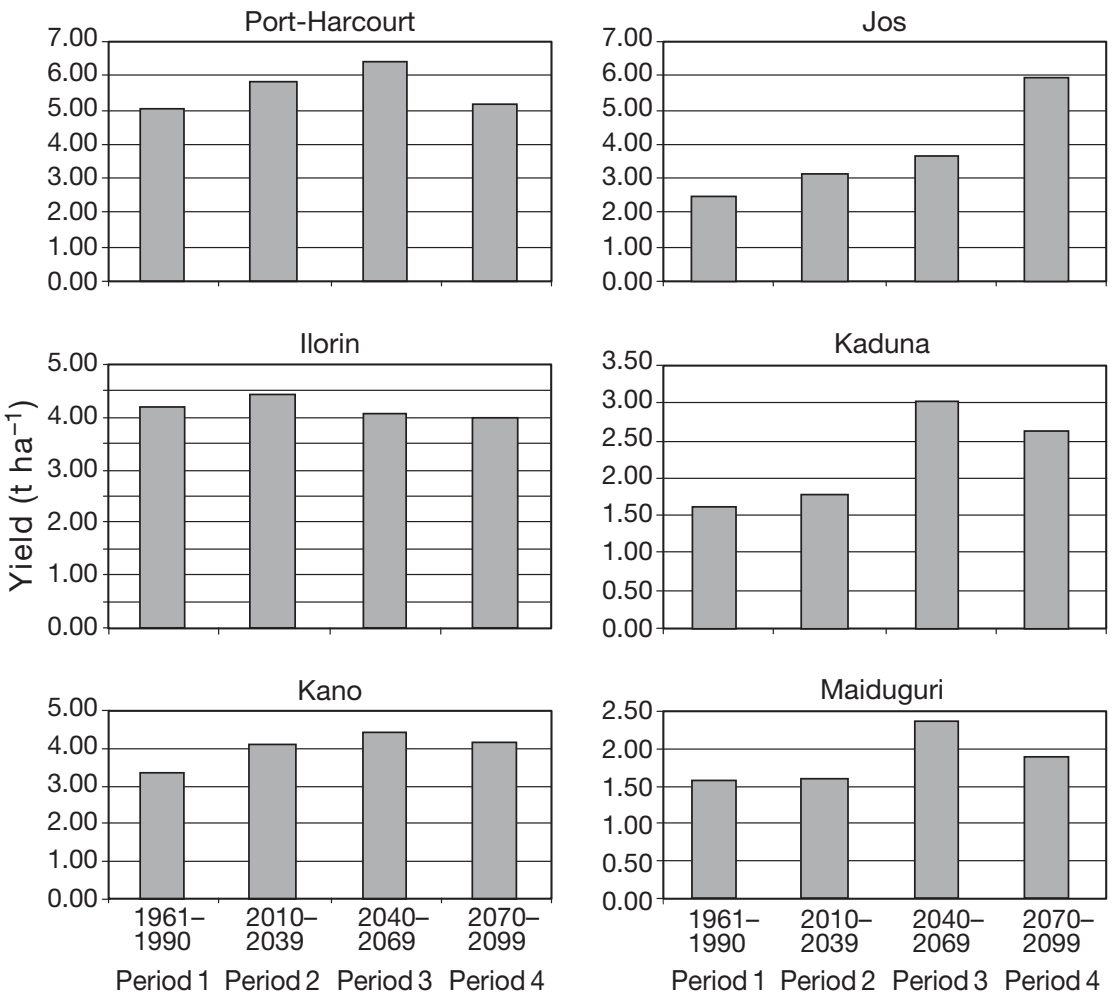

Fig. 2. Maize yield projections 1961-2099 
was recorded for the 1961-1990 period. Increases in yield, projected to start during the second period early in the 21st century, are projected to continue until the end of the century. For Kano, which represents the Sudan savannah ecology, Maiduguri (Sahelian ecology), Kaduna (Northern Guinean ecology) and Port Harcourt, (forest zone ecology), peak yields are projected for the third period (20402069). For Ilorin, which represents the Southern Guinean ecology, peak yield is projected for the second period (2010-2039). The yield projected for the fourth period is lower than the yield recorded for the first.

The general increase in yield is explained in part by increases in $\mathrm{CO}_{2}$ concentration. The steady increase in yield at the high altitude location corresponds to a steady decline in water stress from $47 \mathrm{~d}$ during the 1961-1990 period to $15 \mathrm{~d}$ during the fourth period, i.e. 2070-2099. The duration of temperature stress also declined from 2.6 to $0.5 \mathrm{~d}$. Since the high altitude site also experienced the general warming trend, one could conclude that the current temperature levels are sub-optimal and that the warmer days ahead provide environmental conditions for enhanced yield of maize. However, the steady and significant increases in the yield of maize, especially in the drier zones, are related to increased rainfall and not increased temperature. In Maiduguri, which falls into the Sahelian ecological zone, the increases in yield from 1961 to 2069 correspond to a decline in water stress from 46 to $28 \mathrm{~d}$. However, the further decline to $25 \mathrm{~d}$ during the fourth period seems not to be reflected in continued increase in crop yield. It appears that by the time of the fourth period, the rising temperature would have taken over as the limiting factor. In other words, the decline in crop yield from 2.75 to $2.31 \mathrm{t} \mathrm{ha}^{-1}$ could be ascribed to the increase in temperature stress from 8 to $11 \mathrm{~d}$. One should note here that across the country and across the 4 periods, the experiments did not show any stress related to nitrogen, phosphorus and aeration. When selecting the soil with which to create the soil files used, I adopted the more commonly-cultivated soil series, which in most cases are of moderate productivity. In addition, $300 \mathrm{~kg}$ $\mathrm{ha}^{-1}$ of NPK (Nitrogen Phosphorus Potassium) was applied as part of the operations schedule.

.

\subsection{Sorghum}

Changes in sorghum yield follows 3 patterns (Fig. 3). Firstly, at some sites, continuous increases in yield are projected from the baseline period to Period 4. This is the pattern observed at Jos and Kaduna. However, while the projected increases at Jos (the high altitude location) are evenly distributed from the baseline to Period 4, at Kaduna, the increases tend to slow down from about 2040 onwards in the manner of the upper end of a sigmoid curve. Secondly, at Ilorin, Port Harcourt and Kano, projected yields will peak mid-century (Period 3). Thirdly, at Maiduguri, yields are projected to first decline in Period 2, increase during Period 3 and decline again during Period 4. The general increase in yield is explained in part by increases in $\mathrm{CO}_{2}$ concentration. At Jos (the high altitude site), as evidenced by changes in the stress factors, temperature and moisture are projected to become progressively more favourable with climate change. It appears that temperature was lower than the minimum temperature tolerated during the baseline period. Therefore, the general rise in temperature results in the removal of the stress. At Port Harcourt (forest zone) the initial increase in projected yield from Period 1 to Period 2 seems to have been a result of the decrease in water stress. The decline in yield from Period 3 to Period 4 seems to have resulted from the continued increases in temperature, resulting in temperature stress increasing from $<1$ to $>4 \mathrm{~d}$.
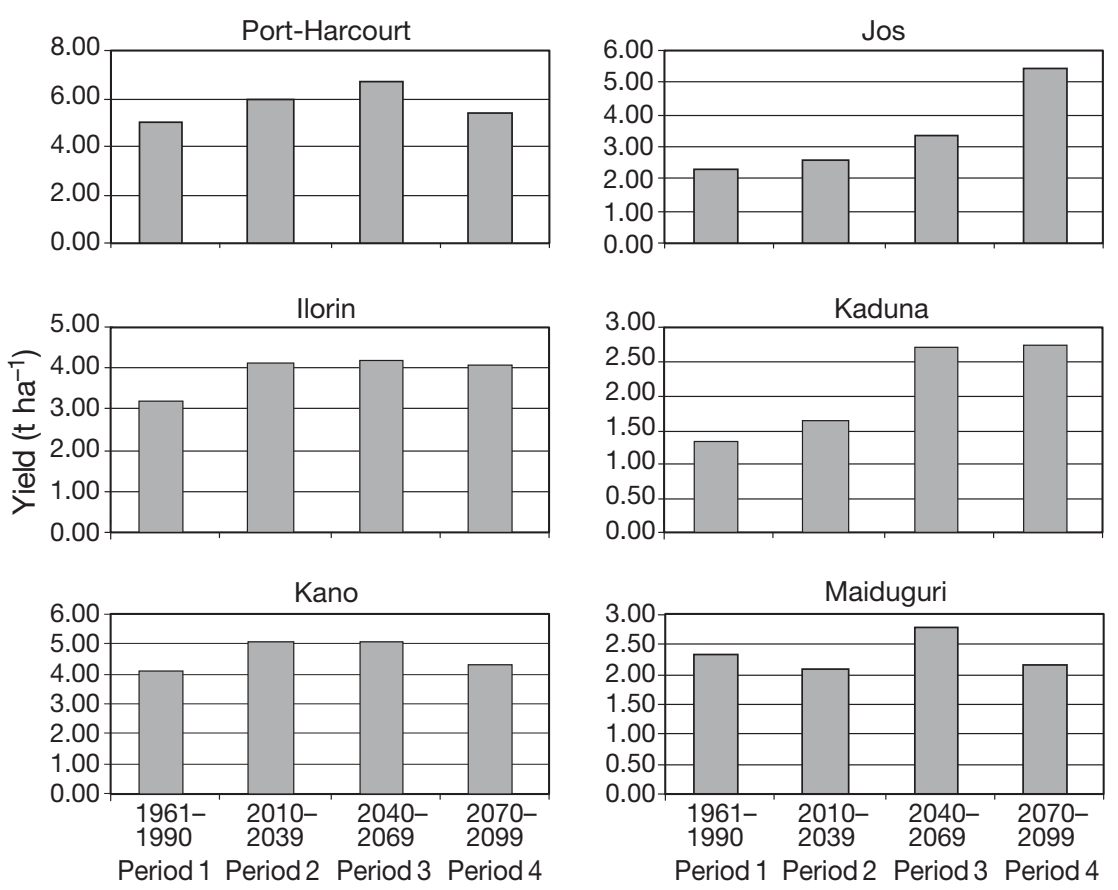

Fig. 3. Sorghum yield projections 1961-2099 


\subsection{Millet}

Millet, like sorghum, demonstrates 3 patterns of yield change over the 140 yr period of study as depicted in Fig. 4. One pattern characterizes Jos, Ilorin and Kaduna, which together represent the sub-humid middle-belt of the country. In this pattern, yields are projected to follow a consistent straight-line increase pattern from the baseline period to Period 4. The second pattern characterizes the forest-based location of Port Harcourt and the semi-arid ecology of Kano. After early, significant increases from the baseline period to Period 2, yields are projected to remain high until Period 3 and then notably decline toward the end of the century. The third pattern, obtained for Maiduguri (representing the Sahelian ecology), is unique. Projections are for an initial decline early in the century, followed by an increase between 2040 and 2069, to be followed by another decline between 2070 and 2099.

The general increase in yield is explained in part by increases in $\mathrm{CO}_{2}$ concentrations. Projected increases in the yield of millet from the baseline period to Period 4 at Jos, Kaduna and Ilorin correspond to decreases in water stress and to increases in $\mathrm{CO}_{2}$ concentration. The interpretation here is that the rising minimum and maximum temperatures are not sufficient to impose a limitation either directly as a result of supra-optimal levels or indirectly as a result of increased rates of evaporation and transpiration. For the forest-based site, namely Port Harcourt, the early increases in yield from the baseline period to Period 2 correspond to significant decreases in water stress, apparently a consequence of increased RH. There were no corresponding projected increases in water stress or temperature stress at Port Harcourt that could explain the decrease in yield from Period 3 to 4. With respect to Kano, the increase in yield from the baseline period to Period 2 could be a consequence of the general increase in RH. The decrease in yield from the third to the fourth period does not correspond to significant changes in any stress factor. Some marginal changes in aeration stress were observed. Even though the climate of Kano is classified as semi-arid, rainfall during the months of July and August is usually in excess of $250 \mathrm{~mm}$ per month. This is enough to cause water-logging of the surface soil horizon.

\subsection{Rice}

Like the other crops, rice seems to demonstrate a mixed pattern of responses to climate change across the ecological zones (Fig. 5). The most common pattern is an increase in projected yields up to the third period, followed by a levelling-off or a slight decrease during the fourth period. This pattern could be observed for Maiduguri (Sahelian ecology), Kano (Sudan ecology), Kaduna (Northern Guinea ecology) and Port Harcourt (forest zone ecology). For Jos, representing high altitude ecology, yields are projected to increase, following a steady and consistent pattern from the baseline period to the fourth period. For the Ilorin site (Southern Guinea ecology), projected yields are expected to peak during the second period after a small early increase. Subsequently, yields are projected to decline to about the 1961-1990 level during the third and the fourth periods.

The general increase in yield is explained in part by increases in $\mathrm{CO}_{2}$ concentration and $\mathrm{RH}$. For Port Harcourt (forest zone ecology), the pattern of projected crop yield changes could be explained by declining water stress. Changes in temperature stress are not projected. It could be noted that increases in precipitation are projected for the coastal areas in the climate change scenario briefly described in Section 2. In the Sahelian ecological zone, i.e. Maiduguri, projected increases from the baseline period to the third period correspond to a steady decline in water stress. The slight decline in yield from the third to the fourth period seems to be determined by limits imposed
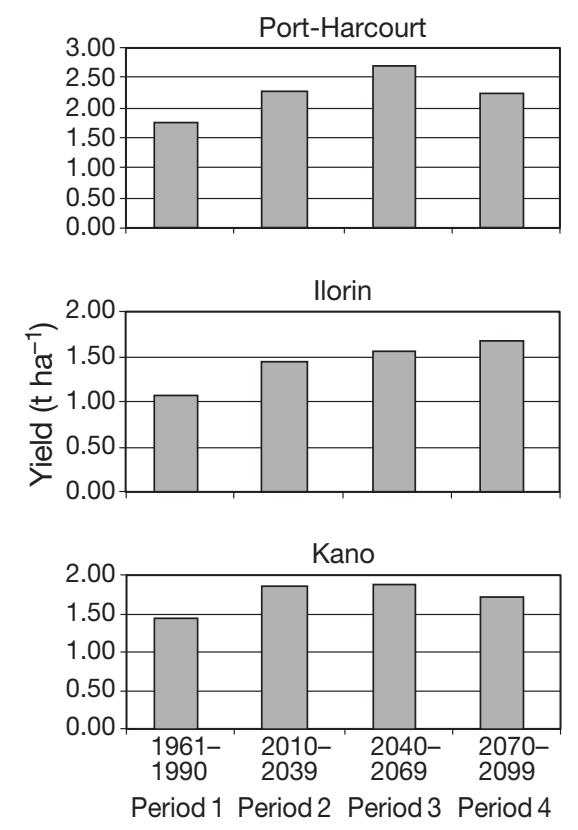
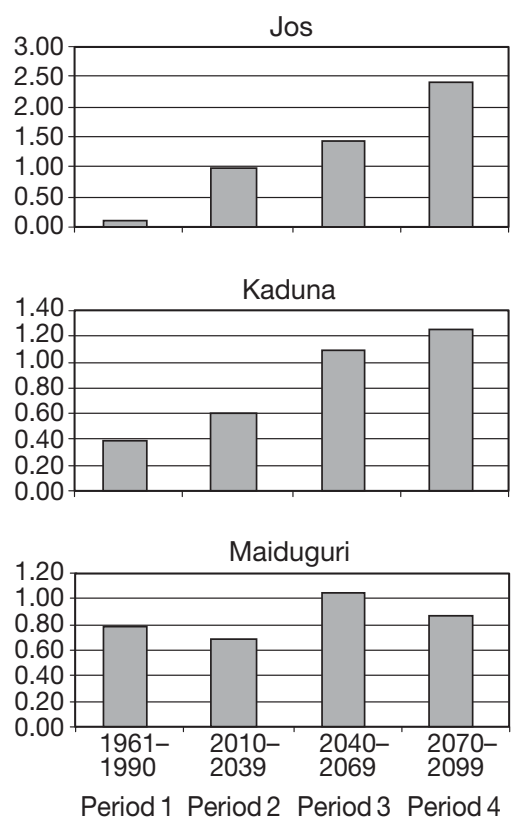

Fig. 4. Millet yield projections 1961-2099 
by the increasing temperature. Even though total annual precipitation is projected to decline, the growing season rainfall does not, according to the climate change projections outlined earlier. Moreover, the levels of rainy season temperature projected are still relatively low during the first 2 periods.

At the high altitude location, projected changes in both water stress and temperature stress appear to favour increases in yield. The steady and consistent increases in yield correspond to steady decreases in water stress resulting from increasing rainfall. Duration of temperature stress declined from 4 to $1 \mathrm{~d}$ from the baseline period to the second period. Subsequently, it increased to $3 \mathrm{~d}$ during the fourth period. However, the negative effects of increased temperature stress during the fourth period appear to have been masked by the positive effects of the lower water stress.

\subsection{Cassava}

Projections depicted in Fig. 6 indicate significant increases in the yield of cassava from the baseline period to the fourth period, in all the semi-arid and sub-humid northern ecological zones. For Kaduna, the increases are from $<300 \mathrm{~kg} \mathrm{ha}^{-1}$ during the baseline period to $>3 \mathrm{t}$ towards the end of the 21st century. The simulations are in essence theoretical because these areas lie outside the current cassava-producing areas. For example, while the simulated yield for Jos during the baseline period is only $800 \mathrm{~kg} \mathrm{ha}^{-1}$, that for Port Hacourt is as high as $8 \mathrm{t} \mathrm{ha}^{-1}$. As a confirmation of this, water stress in Kaduna ran as high as 114 to 175 d compared with <20 d for Port Harcourt. Cassava is a 2-season crop: the stress is computed for its entire growing period. The increases being projected for the northern, more arid zones are indicative that the cultivation range may be extended northwards in response to climate change. Such an extension could be based on increased temperature at the high altitude sites and higher rainfall in the other areas. In Port Harcourt (forest zone), the indica-
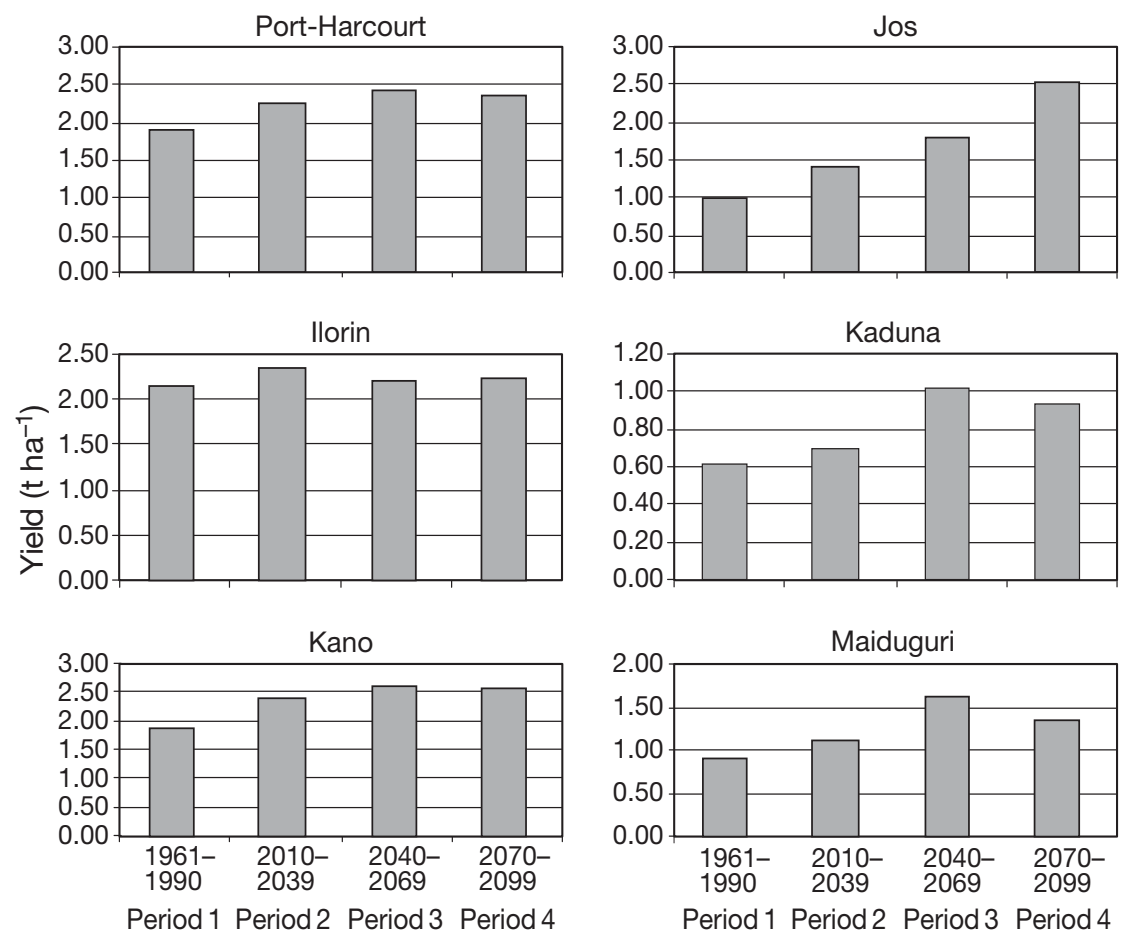

Fig. 5. Rice yield projections 1961-2099
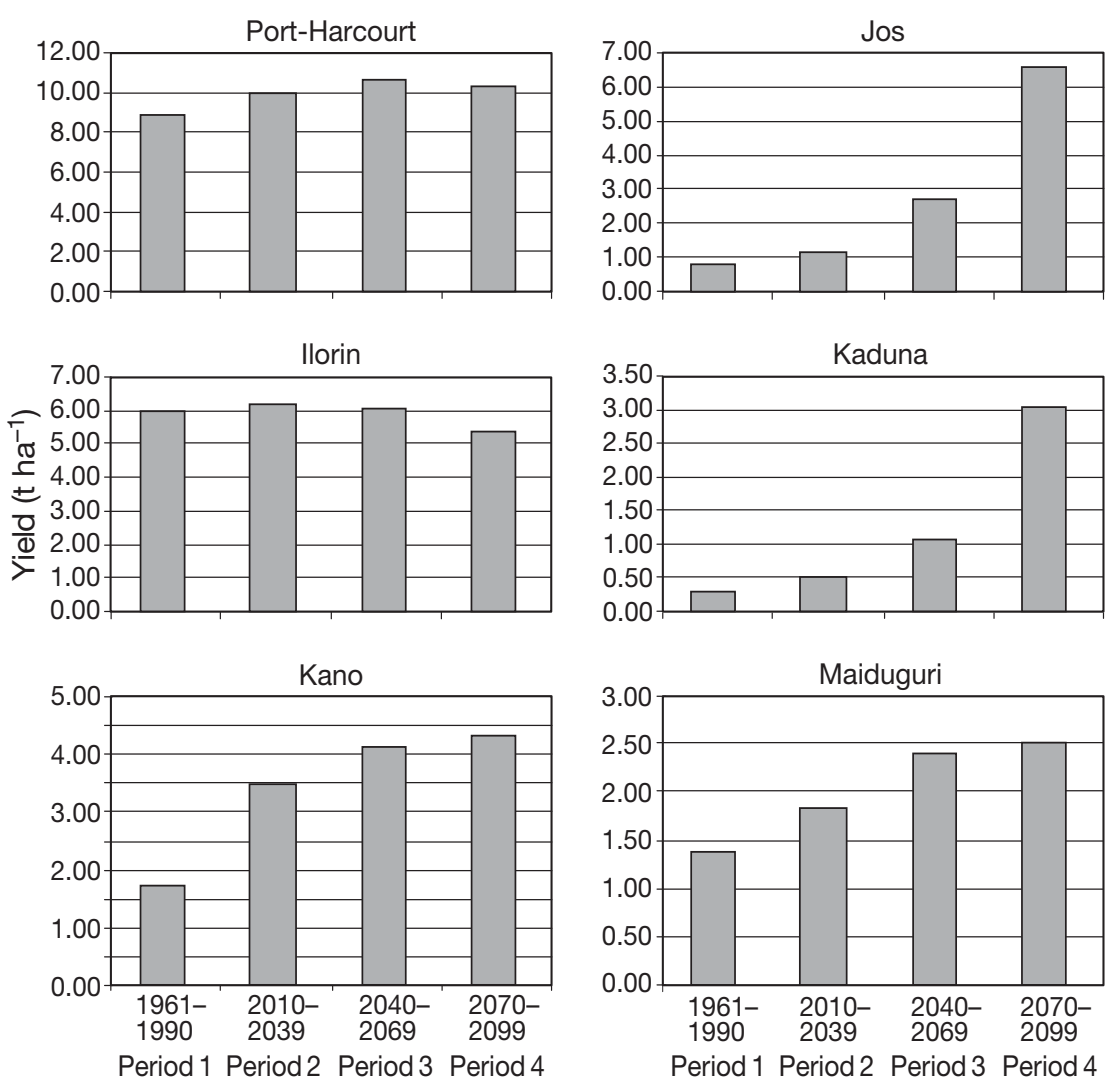

Fig. 6. Cassava yield projections 1961-2099 
tions are a slight increase from $8 \mathrm{t} \mathrm{ha}^{-1}$ during the baseline period to $10 \mathrm{t} \mathrm{ha}^{-1}$ during the third period. The pattern in Ilorin, the sub-humid southern zone, is projected to consist of an initial modest increase followed by a substantial decrease. The initial increase corresponds to a decline in the duration of water stress from 96 to $74 \mathrm{~d}$. The subsequent decreases in projected yield are not supported by a corresponding decrease in water stress. However, during the period, the duration of temperature stress increased from 2 to $7 \mathrm{~d}$ while aeration stress increased from 19 to $29 \mathrm{~d}$.

\section{DISCUSSION}

\subsection{Effects of changing climate parameters}

Farmers' most common response to the problem of rainfall variability is the changing of planting dates, the assumption being that avoidance of the earlier parts of the growing season, when rainfall is more variable, can result in enhanced productivity. In the results presented earlier, however, lower rather than higher yields were recorded for May plantings (when the season was well under way) compared with March plantings (at the beginning of the season), despite the increased rainfall and reduced water stress for crops planted in May. In the current set of experiments, the probable explanation appears to be the higher levels of aeration stress for May compared with March plantings. While the maize crop planted in March did not experience any aeration stress, the crop planted in May experienced $18 \mathrm{~d}$ of aeration stress. Similar observations are made with respect to sorghum and millet, which like maize are upland crops. However, no such contrasts in aeration and water stresses between March and May plantings were observed with respect to rice, which prefers wetter conditions. It thus appears that the negative effects of increasing aeration stress could override the positive effects of decreasing water stress.

The decrease in yield associated with delayed planting dates has been explained in an experiment conducted on the research farm of Obafemi Awolowo University, Nigeria (Fakorede 1985). The decrease in yield was ascribed to the higher levels of solar radiation received during the earlier parts of the growing season. The climate data from Ilorin and the university site indicate that sunshine hours, average daily temperature, evaporation and accumulated heat units decreased as the season progressed, whereas $\mathrm{RH}$ increased. Although maize planted in March could receive as much as $5 \mathrm{~h}$ of full sunshine per day during the grain filling phase, those planted in early May might not even receive as much as $3 \mathrm{~h}$ of full sunshine per day for grain filling. Osafo (1976; working in Kumasi, Ghana), and Cooper \& Law (1977; working in Kenya) arrived at similar conclusions.

Some of the effects of climate on crop yield can only be understood in the broader context. There is, for example, the decrease in yield associated with increased rainfall when the values of the other factors are not changed. Crop plants require specific amounts of materials for optimum performance and maximum yield; additional supplies that are in excess of optimum requirements will not lead to enhanced yields, and may lead instead to reduced yields. This ecological principle is derived from a combination of Liebig's 'law of the minimum' and Shelford's 'law of tolerance' (Liebig 1840, Shelford 1913, Odum 1971). The water requirement of plants is assumed to be fully met when the water available through precipitation is sufficient to balance potential evapotranspiration (Garnier 1960). At Ibadan, measured potential evapotranspiration amounted on average to about $75 \mathrm{~mm}$ during the humid growing season (Garnier 1961). The implication of this for crop yield response to climate change is that whenever baseline precipitation is $>75 \mathrm{~mm}$, additional rainfall will not result in additional crop yield. Additional rainfall could also result in reduced crop yield, owing to the fact that it contributes to increased gravitational soil water and increased aeration stress.

Furthermore, the way in which increases in $\mathrm{RH}$ are converted to increases in yield is not clear from the results, as neither water stress nor aeration stress seem to be affected for any of the crops, whether planted in March or in May. It is conceivable that increasing RH leads to higher rates of dew formation. Dew formed on leaves could be absorbed through the cuticle of normal epidermal cells, or through specialised cells, thus providing an alternative source of moisture and avoiding the much more stressful uptake of soil water through root hairs (Daubenmire 1974). While water intake through root hairs is subject to limitation by the absorptive capacity of the atmosphere exercised through evaporation and transpiration, water intake from the leaf surface may not be subject to such limits and could permit the crop plants to breach the limits of crop performance that are normally based strictly on rates of evapotranspiration.

It appears that, in general, higher temperatures create more favourable conditions for crop growth at the higher altitude site. This is to be expected, because baseline temperatures are sub-optimal. As the climate becomes warmer, the temperature approaches the level required for optimum performance, and crop yield is enhanced. On the other hand, baseline temperatures at the low altitude site appear to be supraoptimum. Thus, as the climate becomes warmer, tem- 
perature approaches the upper limits of tolerance and a decline in yield materialises.

The minimum temperatures at Ibadan and at Jos, the experimental sites, are lower than the optimum temperature for most varieties of the crop plants. The lower end of the range of tolerance for maize is $26^{\circ} \mathrm{C}$ (Johnston 1958). Thus, there could be potential for increased temperature to promote increased yield of maize before the maximum temperature begins to constrain yield (as observed for Ibadan in Table 3). Furthermore, before this point is reached, the increases in yield will become smaller. The simulation outputs seem to have captured this stage for maize and sorghum (see Ibadan values in Table 3 ).

In the EPIC model the potential yield is determined primarily by the amount of solar radiation received. The other climatic-determining factors play a constraining role in reducing the potential yields (Williams et al. 1989). This conforms to the explanations of Fakorede (1985) and Osafo (1976) regarding the higher yields of March compared with May plantings of maize. It also conforms to our observations from an earlier study, to the effect that lower amounts of solar radiation that characterize the main growing season months in Nigeria tend to depress the yield of maize (Adejuwon 2002). It is conceivable that the levels of solar radiation received at the experiment site during the growing season for the 1961-1990 period were sub-optimal for the current varieties of the crop (see Table 4). If changes in climate turn out in reality to be as they are currently projected (Houghton et al. 2001), West Africa may experience substantial increases in the yields of cereal crops, not only as a result of increases in moisture supply or temperature, but also in response to higher levels of solar radiation.

Besides solar radiation, $\mathrm{CO}_{2}$ in the atmosphere and water from both the soil and the atmosphere are essential for the processes of photosynthesis or primary biological productivity. One would expect an enhanced level of $\mathrm{CO}_{2}$ concentration in the atmosphere to increase the gradient between the external air and the air spaces inside the leaves, thus promoting higher levels of diffusive transfer and absorption of $\mathrm{CO}_{2}$ into the chloroplasts and higher levels of photosynthesis and biological productivity. Another important physiological effect of $\mathrm{CO}_{2}$-enrichment is the closure of stomata. Accordingly, a rise in atmospheric $\mathrm{CO}_{2}$ may reduce transpiration even while promoting photosynthesis. This dual effect may improve water-use efficiency (Fischer 1996). Therefore, higher concentrations of atmospheric $\mathrm{CO}_{2}$ should also induce plants to be more economical in the use of water. With higher concentrations of $\mathrm{CO}_{2}$, crops should be less subject to water stress in areas normally considered marginal with respect to precipitation. The sensitivity of maize to changes in atmospheric concentration of $\mathrm{CO}_{2}$ at Jos in Central Nigeria (Table 4) confirms this.

However, according to Fischer (1996), plant species vary in their response to $\mathrm{CO}_{2}$-enrichment in part owing to differing photosynthetic mechanisms. $\mathrm{C}_{3}$ plants (wheat, rice, and soybean) use part of the solar energy they absorb in photorespiration. In this process, some of the carbon fixed into carbohydrates is re-oxidised to $\mathrm{CO}_{2} . \mathrm{C}_{3}$ species tend to respond readily to increased $\mathrm{CO}_{2}$ levels because photorespiration is suppressed under these conditions. On the other hand, in $\mathrm{C}_{4}$ plants (maize, millet, sorghum and sugarcane), $\mathrm{CO}_{2}$ is trapped inside the leaf and becomes concentrated in the cells that carry out photosynthesis. These plants are more photosynthetically-efficient under current levels of $\mathrm{CO}_{2}$ concentration. This explains the progressively smaller responses of maize sorghum and millet, which are $\mathrm{C}_{4}$ plants, to higher $\mathrm{CO}_{2}$ concentrations. The response of rice, a $\mathrm{C}_{3}$ plant, to the same levels of $\mathrm{CO}_{2}$ concentrations appears to be much more vigorous. With $\mathrm{CO}_{2}$ concentration at $650 \mathrm{ppm}$, the percentage change in yield over baseline was 8.1 for maize, 7.0 for sorghum and 12.3 for millet compared with 20.8 for rice (Table 4).

\subsection{Effects of projected climate change on the yield of each crop}

Increases in crop yield during the first half of the 21st century are probably related to lower water stress as a result of increased rainfall, higher levels of incident solar radiation resulting from less cloud cover, and higher levels of $\mathrm{CO}_{2}$ concentration resulting from unmitigated increases in anthropogenic emissions. The reduction in yields towards the end of the century could be ascribed to the attainment of supra-optimum levels of temperature and $\mathrm{CO}_{2}$ concentrations.

It should be noted that the climate change scenario used for the assessment of the current study assumes $1 \%$ per annum increases in the concentration of atmospheric $\mathrm{CO}_{2}$. The assumption is based on failure to put into practice the prescriptions of the Kyoto Protocol, a lack of progress in developing alternative sources of energy to fossil fuels and continued high rates of population increase. In other words, this study has adopted a 'worst case' climate change scenario. Ironically, the worst-case climate change scenario appears to be producing a 'best-case' food production scenario. There are other equally plausible climate change scenarios based on lower rates of increase in concentrations of atmospheric greenhouse gases. If any of these should turn out to be closer to the course of the real world changes in global climate, the effects on crop yield may be substantially different from that outlined 
above. While the direction of change may be the same, the magnitude of change could be quite different. It may take up to $100 \mathrm{yr}$ to attain what the foregoing assessment suggested would be realized in 50 yr. In other words, we might not have reached the stage of declining crop yield by 2100, and crop yield changes may remain positive until the end of the 21st century.

\section{SUMMARY AND CONCLUSIONS}

In the present study, EPIC was used in the assessment of the effects of climate change on the yield of maize, sorghum, rice, millet and cassava. Yam, which is also listed among the major food crops in Nigeria, was not included in the study because it is not on the EPIC crop list. Sensitivity of the various crops to changes in climate elements was demonstrated. The model was used to show crop yield response to changes in rainfall, solar radiation, temperature, $\mathrm{RH}$ and $\mathrm{CO}_{2}$.

Solar radiation is the primary determinant of biomass yield from which other yields are derived (Williams et al. 1989). Climate change projections by the various GCMs for West Africa are for a higher level of solar radiation as a consequence of lower levels of cloud cover. From our own findings, the decrease in cloud cover with respect to the 1961-1990 mean is projected to continue to the end of the 21st century.

The indications are that, in general, there will be increases in crop yield across all ecological zones as the climate changes during the 21st century. In most cases, the increases will continue until mid-century. However, towards the end of the century, the rate of increase will tend to slow down. This could result in yields that are lower in the last quarter than in the third quarter of the century. The yield increases during the earlier parts of the century will not be completely reversed. Thus, for the century as a whole, the projections are for a net increase. As should be expected, there will be significant differences between the various ecological zones. For example, there will be substantial increases in the yield of cassava in the drier areas compared with the rainforest zone, where there may be a net decrease in yield. The implication of this is that the cassava-growing region could be extended northwards. However, yield in the wetter forest areas will still remain much higher than yield in the north. Another exception to the general trend is that yield of all the crops will continue to increase right to the end of the century on the high altitude Jos Plateau.

In conclusion, for the rest of the current century, the risks of crop failure due to occasional droughts will most likely remain. As the climate changes during the first half of the century, risks of crop failure will most likely be tempered due to crop yield increases in response to higher levels of solar radiation, rainfall, atmospheric humidity and $\mathrm{CO}_{2}$ concentrations. However, during the second half of the century, the risks of crop failure will be driven by a new set of climatic factors, especially those based on increasing global warming. The current moisture-based limiting factors are projected to be replaced by temperature-based ones. In the context of limiting-factor ecology, supraoptimum temperatures will tend to replace inadequate moisture as the factor most closely approaching the limits of tolerance of the crop plants and therefore most likely to determine changes in crop yield.

Acknowledgements. This study was conducted as part of a research project funded and supported by 3 organizations: START (SysTem for Analysis, Research and Training), NOAA (USA National Oceanic and Atmospheric Administration) and AIACC (Assessment of Impacts of and Adaptations to Climate Change). The supporting organizations for AIACC are: START, TWAS (Third World Academy of Sciences) and UNEP (United Nations Environment Programme).

\section{LITERATURE CITED}

Adejuwon JO (2002) Extended weather forecasts as a management tool for the enhancement of crop productivity in Sub-Saharan West Africa. J Niger Meteorol Soc 3:25-38

Adejuwon JO (2005a) Food crop production in Nigeria. I. Present effects of climate variability. Clim Res 30:53-60

Adejuwon JO (2005b) Assessing the suitability of EPIC Crop Model for use in the study of impacts of climate variability and climate change in West Africa. Singapore J Trop Geogr 24:44-60

Adejuwon JO, Omotayo MO (2006) Potential climate change in Nigeria during the 21st century: the worst case scenario. In: Adejuwon JO, Ogunkoya OO (eds) Climate variability, climate change and food security in Nigeria. Obafemi Awolowo University Press, Ile-Ife

Adejuwon JO, Balogun EE, Adejuwon SA (1990) On the annual and seasonal patterns of rainfall fluctuations in Sub-Saharan West Africa. Int J Climatol 10:839-848

Butler JW, Riha Riha SJ (1989) GAPS: a general purpose formulation model of the soil-plant-atmosphere system, version 1.1 User's manual. Department of Agronomy, Cornell University, Ithaca, NY

Cabelguenne $\mathrm{M}$, Jones CA, Marty JR, Dyke PT, Williams JR (1990) Calibration and validation of EPIC for crop rotations in southern France. Agric Systems 33:153-171

Cooper PJM, Law R (177) Soil temperature and its association with maize yield variation in the highlands of Kenya. J Agric Sci 89:355-363

Daubenmire RF (1974) Plants and environment: a text book of plant autecology, 3rd edn. John Wiley \& Sons, New York

Easterling WE, Rosenberg NJ, McKenney MS, Jones CA, Dyke PT, Williams JR (1992) Preparing the erosion productivity impact calculator (EPIC) model to simulate crop response to climate change and the direct effects of $\mathrm{CO}_{2}$. Agric For Meteorol 59:17-34

Easterling WE, Crosson PR, Rosenberg NJ, McKenney MS, Katz LA, Lemon KM (1993) Agricultural impacts of and 
responses to climate change in the Missouri-IowaNebraska-Kansas (MINK) Region. Clim Change 24:23-62 Easterling WE, Chen X, Hays C, Brandle JR, Zhang H (1996) Improving the validation of model-simulated crop yield response to climate change: an application to the EPIC model. Clim Res 6:263-273

Fakorede MAB (1985) Response of maize to planting dates in a tropical rain forest location. Explor Agric 21:19-50

Fischer G, Frohberg K, Keyzer MA, Parikh KS (1988) Linked national models: a tool for international policy analysis. Kluwer, Amsterdam

Fischer G, Frohberg K, Parry ML, Rosenzweig C (1996) Impacts of potential climate change on global and regional food production and vulnerability. In: Downing TE (ed) Climate change and world food security. SpringerVerlag, Heidelberg, p 115-160

Garnier BJ (1960) Maps of water balance in West Africa. Bull IFAN Ser A 22:709-722

Garnier BJ (1961) Delimitation of the humid tropics. Geogr Rev 51:339-347

Houghton JT, Meira Filho LG, Bruce J, Lee H, Callander BA, Haites E, Harris N, Maskell K (1995) Climate change 1994. Radiative forcing of climate change and an evaluation of the IPCC IS92 emission scenarios. Cambridge University Press, Cambridge

Houghton JT, Ding Y, Griggs DJ, Noguer M, van der Linden PJ, Xiaosu D (2001) Climate change 2001: the scientific basis. Contribution of Working Group I to the Third Assessment Report of the Intergovernmental Panel on Climate Change. Cambridge University Press, Cambridge

Hulme M, Wigley TML, Barrow EM, Raper SCB, Cantella A, Smith S, Chipanshi AC (2000) Using a climate scenario generator for vulnerability and adaptation assessments: MAGICC and SCENGEN version 2.4. University of East Anglia, Norwich

Hulme M, Doherty R, Ngara T, New M, Lister D (2001) African climate change: 1900-2100. Clim Res 17:145-168

Ibigbami IA, Areola O, Akintola F (1979) The soils of the lower Ngeli Plain, Plateau state (a preliminary soil survey for irrigated agriculture). University of Ibadan, Ibadan

Johnston BF (1958) The staple food economies of western tropical Africa. Stanford University Press, Stanford, CA

Jones JW, Boote KJ, Hoogenboom G, Jagtar SS, Wilkerson GG (1989) SOYGRO V 5.42, soybean crop growth simulation model, User's guide. Department of Agricultural Engineering and Department of Agronomy, University of Florida, Gainsville

Keay RWJ (1959) An outline of Nigerian vegetation. Government Printer, Lagos

Kiniry JR, Spanel DA, Williams JR, Jones CA (1990) Demonstration and validation of crop grain yield simulation by EPIC. US Dept Agric Tech Bull 1768:220-235

Liebig J (1840) Chemistry and its applications to agriculture and physiology. Taylor \& Walton, London

McKenney MS, Easterling WE, Rosenberg NJ (1992) Simulation of crop productivity and responses to climate change in the year 2030: the role of future technologies, adjustments and adaptations. Agric For Meteorol 59:103-137

Editorial Responsibility: Otto Kinne,

Oldendorf/Luhe, Germany
MOE (Ministry of Environment of the Federal Republic of Nigeria) (2003) Nigeria's first communication under the UNFCCC. MOE, Abuja

Moss RP (1957) Report on the classification of the soils found over sedimentary rocks in Western Nigeria. Ministry of Agriculture and Natural Resources, Ibadan

Murdock G, Ojo-Atere J, Colborne G, Olomu EI, Odugbesan EM (1976) Soils of the Western State savanna in Nigeria. Land Resources Study 23. Land Resources Division, Ministry of Overseas Development, Tolsworth Tower

Nakicenovic N, Swart R (2000) Emission scenarios 2000: Special Report of the Intergovernmental Panel on Climate Change. Cambridge University Press, Cambridge

Nicholson SE (2001) Climatic and environment change in Africa during the last two centuries. Clim Res 17:123-144

Nwaka GIC (1997) Soil survey and fertility baseline data collection for NALDA farm site at Tikau, Yobe state, Nigeria. National Agricultural Land Development Authority, Abuja

Odum EP (1971) Fundamentals of ecology. Saunders College Publishing, Philadelphia, PA

Osafo DM (1976) Weather conditions and the growth of maize in the Kumasi area of Ghana: an analysis of the growth of a maize variety sown on different days. Ghana J Agric Sci 9:25-34

Rinaldi M (2001) Application of EPIC model for irrigation scheduling of sunflower in southern Italy. Agric Water Manage 49:185-196

Ritchie JT (1991) Specification of the ideal model for predicting crop yields. In: Muchow RC, Bellamy JA (eds) Climate risks in crop production: models and management for the semi arid tropics and sub tropics. CAB International, Wallingford, p 97-122

Roloff G, De-Jong R, Nolin MC (1998) Crop yield, soil temperature and sensitivity of EPIC under central-eastern Canadian conditions. Can J Soil Sci 78:431-439

Rosenberg NJ, McKenney MS, Easterling WE, Lemon KM (1992) Validation of EPIC model simulations of crop responses to current climate and $\mathrm{CO}_{2}$ conditions: comparison with census, expert judgement and experimental plot data. Agric For Meteorol 59:35-51

Shelford VE (1913) Animal communities in temperate America. University of Chicago Press, IL

Smyth AJ, Montgomery RF (1962) Soil and land use in central western Nigeria. Government of Western Nigeria, Ibadan

Tsuji GY, Uehara G, Balas S (1994) DSSAT version 3. University of Hawai, Honolulu

Tubiello FN, Rosenzweig C, Goldberg RA, Jagtap S, Jones JW (2002) Effects of climate change on US crop production: simulation results using two different GCM scenarios. Part I: wheat, potato, maize, and citrus. Clim Res 20: $259-270$

USCP (1994) Guidance for vulnerability and adaptation assessment version 1.0. US Country Studies Program, Washington, DC

Williams JR, Jones CA, Kiniry JR, Spanel DA (1989) The EPIC crop growth model. Trans Am Soc Agric Eng 32:498-511

Williams JR, Jones CA, Dyke PT (1990) The EPIC model. US Dept Agric Tech Bull 1768:3-92

Submitted: July 14, 2005; Accepted: April 5, 2006

Proofs received from author(s): October 3, 2006 